\title{
Communication \\ Porcine Circoviruses and Herpesviruses Are Prevalent in an Austrian Game Population
}

\author{
Angelika Auer ${ }^{1}$, Lea Schweitzer ${ }^{1}$, Anna Kübber-Heiss ${ }^{2}$, Annika Posautz $^{2}$, Katharina Dimmel $^{1}$, Kerstin Seitz ${ }^{1} \oplus$, \\ Christoph Beiglböck ${ }^{2}$, Christiane Riedel ${ }^{1, *,+}$ and Till Rümenapf ${ }^{1,+}$
}

1 Institute of Virology, Department of Pathobiology, University of Veterinary Medicine, 1210 Vienna, Austria; angelika.auer@vetmeduni.ac.at (A.A.); 11774488@students.vetmeduni.ac.at (L.S.); katharina.dimmel@vetmeduni.ac.at (K.D.); kerstin.seitz@vetmeduni.ac.at (K.S.); till.ruemenapf@vetmeduni.ac.at (T.R.)

2 Research Institute of Wildlife Ecology (FIWI), Department of Interdisciplinary Life Sciences, University of Veterinary Medicine, 1160 Vienna, Austria; anna.kuebber@vetmeduni.ac.at (A.K.-H.); annika.posautz@vetmeduni.ac.at (A.P.); christoph.beiglboeck@vetmeduni.ac.at (C.B.)

* Correspondence: christiane.riedel@vetmeduni.ac.at

+ These authors contributed equally to this work.

check for updates

Citation: Auer, A.; Schweitzer, L.; Kübber-Heiss, A.; Posautz, A.; Dimmel, K.; Seitz, K.; Beiglböck, C.; Riedel, C.; Rümenapf, T. Porcine Circoviruses and Herpesviruses Are Prevalent in an Austrian Game Population. Pathogens 2022, 11, 305. https://doi.org/10.3390/ pathogens 11030305

Academic Editors: Avi Eldar and Tanja Opriessnig

Received: 10 December 2021

Accepted: 25 February 2022

Published: 28 February 2022

Publisher's Note: MDPI stays neutral with regard to jurisdictional claims in published maps and institutional affiliations.

Copyright: (C) 2022 by the authors. Licensee MDPI, Basel, Switzerland. This article is an open access article distributed under the terms and conditions of the Creative Commons Attribution (CC BY) license (https:// creativecommons.org/licenses/by/ $4.0 /)$.

\begin{abstract}
During the annual hunt in a privately owned Austrian game population in fall 2019 and 2020, 64 red deer (Cervus elaphus), 5 fallow deer (Dama dama), 6 mouflon (Ovis gmelini musimon), and 95 wild boars (Sus scrofa) were shot and sampled for PCR testing. Pools of spleen, lung, and tonsillar swabs were screened for specific nucleic acids of porcine circoviruses. Wild ruminants were additionally tested for herpesviruses and pestiviruses, and wild boars were screened for pseudorabies virus (PrV) and porcine lymphotropic herpesviruses (PLHV-1-3). PCV2 was detectable in 5\% (3 of 64 ) of red deer and $75 \%$ (71 of 95) of wild boar samples. In addition, 24 wild boar samples (25\%) but none of the ruminants tested positive for PCV3 specific nucleic acids. Herpesviruses were detected in $15(20 \%)$ ruminant samples. Sequence analyses showed the closest relationships to fallow deer herpesvirus and elk gammaherpesvirus. In wild boars, PLHV-1 was detectable in 10 (11\%), PLHV-2 in $44(46 \%)$, and PLHV-3 in $66(69 \%)$ of animals, including 36 double and 3 triple infections. No pestiviruses were detectable in any ruminant samples, and all wild boar samples were negative in PrV-PCR. Our data demonstrate a high prevalence of PCV2 and PLHVs in an Austrian game population, confirm the presence of PCV3 in Austrian wild boars, and indicate a low risk of spillover of notifiable animal diseases into the domestic animal population.
\end{abstract}

Keywords: wild boar; wild ruminants; porcine lymphotropic herpesvirus; PCV2; PCV3; ruminant gammaherpesvirus

\section{Introduction}

Wild animal populations can be affected by diseases introduced by domestic animals, but can also be conceived as a threat to domestic animal populations as potential vectors or reservoirs of disease. Therefore, monitoring wildlife health is an important tool to analyze disease dynamics in wild populations and the effect and likelihoods of spill-over to domestic animals and vice versa.

Important pathogens of domestic animals that are also present in wild ruminants and wild boar are, for example circoviruses, herpesviruses, and pestiviruses. Porcine circovirus type 2 (PCV2) is a small, circular, single-stranded DNA virus of the family Circoviridae. It plays an important role in pig production worldwide and is known to cause postweaning multisystemic wasting syndrome (PMWS); porcine dermatitis and nephropathy syndrome (PDNS); and other diseases such as respiratory problems, enteritis, and reproductive failure [1-5]. PCV2 is highly prevalent in European wild boar populations, but associated clinical disease is rarely observed [6-15]. 
Porcine circovirus type 3 (PCV3) was discovered in pigs in 2016 and is highly prevalent in the domestic pig population [16]. It is associated with different syndromes, such as PDNS and reproductive failure [17-34]. Comparable to PCV2, PCV3 can also be detected in healthy pigs, and its distribution in the wild boar population seems to be similar to domestic pigs, ranging from $23 \%$ to $50 \%$ [15,35]. Porcine circoviruses were also detected in chamois, roe deer, dogs, cattle, mice, and ticks, but the clinical relevance in these species is unclear [36-41].

Aujeszky's disease is caused by suid alphaherpesvirus 1 (SuHV-1, PrV) and is endemic in most parts of the world. Its economic impact led to its eradication from the domestic pig populations of many European countries. PrV remains prevalent in European wild boar populations [42-45] and mostly results in asymptomatic infection. It causes rabies-like and always fatal disease in many different mammalian species other than swine. Hunting dogs, which come into contact with blood or raw wild boar meat, are frequently infected $[46,47]$.

The role of gammaherpesviruses in human and animal health is still not fully understood. As they have certain sequence homologies to human herpesviruses (HHV-4/EBV and $\mathrm{HHV}-8$ ), porcine lymphotropic herpesviruses (PLHV-1, -2 , and -3) has raised the interest of scientists investigating pig-to-human xenotransplantation and post-transplant lymphoproliferative disease (PLTD). PLHV-1, -2, and -3 are highly prevalent in domestic pigs in Germany, Italy, Ireland, and Spain. Infected animals are clinically healthy [48-51], but an influence on the host's immune system caused by the infection of B-lymphocytes has been proposed by the authors of [49]. PLHV-1 and -2 were also detected in a German feral pig population, but only a few samples have been analyzed to date $[48,49]$.

Gammaherpesviruses of the Lymphocryptovirus genus, such as ovine herpesvirus 2 (OvHV-2), caprine herpesvirus 2 (CpHV-2), and alcephaline herpesvirus 1 (AlHV-1), are well adapted to their host's immune system and mainly cause subclinical infections. They can cause lymphoproliferative malignant catarrhal fever (MCF) if transmitted to cattle, buffalo, bison, sika deer, or even pigs [52-57]. Other gammaherpesviruses like elk gammaherpesvirus or fallow deer herpesvirus are not known to be associated with disease. They may influence the animal's immune system or can cause lymphoproliferative diseases in other species $[58,59]$.

The ruminant pestiviruses border disease virus (BDV) and bovine viral diarrhea virus (BVDV) (family Flaviviridae) can infect various ungulate species. Starting in 2004, a national eradication program succeeded to eliminate BVDV from Austrian cattle herds. Still, there is a certain risk of re-introduction of pestiviruses into cattle herds by indirect contact with infected deer. Reported seroprevalences in Austria and Switzerland are low ( 2\%). In Spain, seroprevalences range from $11 \%$ to $20 \%$ in red deer samples, and it has been demonstrated that wild ruminants have the potential to transmit the virus [60-63]

In the present study, we generated a snapshot of the circulation of circo-, herpes-, and pesti-viruses, as well as the morbidities present at necropsy in an Austrian game population. The study's aim is to increase our understanding of the circulation and viral loads of relevant pathogens of domestic animals in Austrian game, and to further our knowledge of the biology of gammaherpesviruses and their pathological significance in game species. Here, 75 wild ruminants and 95 wild boars shot during canned hunts in fall 2019 and 2020 were sampled for the purpose of this study. Different herpes virus species were identified by sequence analysis in the ruminant population, and the viral loads of PCV2; PCV3; and PLHV-1, -2, and -3 were analyzed. The studied game population lives in a $12 \mathrm{~km}^{2}$ forest area surrounded by a stone wall and has not been restocked for at least ten years.

\section{Results}

Most animals in this study had a moderate to good body condition (BCS 2 or larger; wild boar $95 \%$ and wild ruminants $87 \%$ ). Poor body condition was only observed in juvenile animals. The gross pathological examination revealed enteritis in $30 \%$ of the wild ruminants, lung lesions in 17\%, liver lesions in $21 \%$, and localized lymphadenopathy in 
$39 \%$ of the wild ruminants. For wild boar, milk spots (chronic interstitial hepatitis caused by Ascaris suum) were detected in $23 \%$, intestinal parasites in $85 \%$, and lungworms in $46 \%$ of the individuals sampled. In addition, $18 \%$ of the wild boar exhibited localized lymphadenopathy and $7 \%$ exhibited a suppurative lymphadenitis or abscesses in the mandibular lymphnodes.

During necropsy, samples were taken by aspiration with sterile needles from the liver and spleen to avoid environmental contamination and cross-contamination between different animals. Viral nucleic acids extracted from tissue samples and swabs were analyzed for the presence of the following viral pathogens: wild ruminants, herpesviruses, pestiviruses, PCV2, and PCV3, and wild boar, PCV2 and 3, PLHV-1-3, and PrV. The presence of viruses and virus infection were analyzed for associations with age, BCS, and comorbidities.

In 34 out of 50 (68\%) wild boar samples in 2019 and 37 out of 45 in 2020 (82\%), PCV2 was detected by qPCR (Figure 1).

A

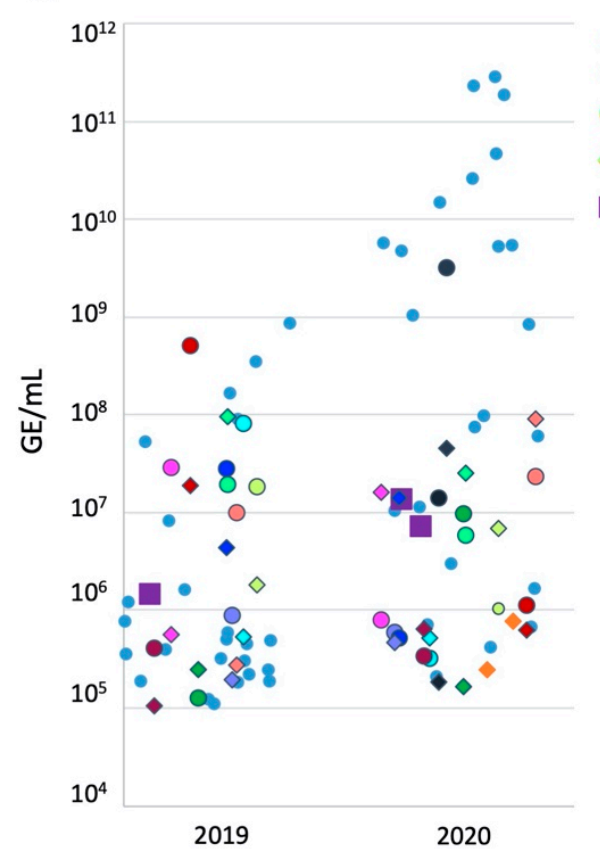

B

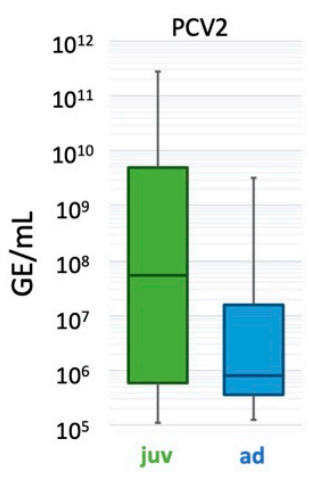

Figure 1. Virus loads of PCV2 and PCV3 in wild boar and red deer samples in GE (genome equivalents)/mL sample. (A) Samples of wild boar only testing positive for PCV2 are depicted as blue dots, and those testing only positive for PCV3 as orange diamonds. Values of wild boar samples testing positive for PCV2 (dot) and PCV3 (diamond) are indicated by the same color for each individual sample. Red deer samples positive for PCV2 are indicated by purple squares. No PCV3 infection was detected in wild ruminants. PCV2 (B) and PCV3 (C) virus loads depending on the age of the sampled wild boar.

Viral loads ranged from $1.12 \times 10^{5} \mathrm{GE}$ (genome equivalents) $/ \mathrm{mL}$ to $8.75 \times 10^{8} \mathrm{GE} / \mathrm{mL}$ in 2019 (average $6.63 \times 10^{7}$, viral loads are given in GE/mL due to the sampling strategy used). In 2020, $2.1 \times 10^{5}$ to $2.9 \times 10^{11} \mathrm{GE} / \mathrm{mL}$ (average $2.2 \times 10^{10}$ ) were present in the samples of positive wild boars, and 10 wild boars had viral loads above $1 \times 10^{9} \mathrm{GE} / \mathrm{mL}$ sample. The PCV2 viral loads in 2019 and 2020 differed significantly $(p=0.048)$. Higher virus loads were significantly associated with the age of the animals $(p=0.049)$, with juveniles presenting with higher loads (Figure 1B).

In 2019, 10 wild boars positive for PCV2 also tested positive for PCV3 (29\% of PCV2 positive animals, $20 \%$ of animals tested, GE/mL ranging from $1.1 \times 10^{5}$ to $9.5 \times 10^{7}$ ). Two wild boars sampled in 2020 only tested positive for PCV3 (4.4\%), while 12 out of 37 PCV2 positive wild boars also were infected with PCV3 (32\% of PCV2 positive individuals, $27 \%$ of 
individuals tested, $\mathrm{GE} / \mathrm{mL}$ ranging from $1.7 \times 10^{5}$ to $9.1 \times 10^{7}$ ). At least in this small study population, PCV3 seemed to be predominantly present as co-infection with PCV2. PCV3 infection was significantly associated with lower PCV2 loads in $2020(p=0.049)$. No PCV3 infection was observed in wild boars with a BCS below 2 (all data generated by this study are available in Supplementary Table S1) and the infection was significantly associated with age $(11 \%$ of juveniles virus positive and $37 \%$ of adults virus positive, $p<0.01)$, while the virus loads seemed comparable (Figure 1C).

Three out of 75 wild ruminants (4\%) tested positive for PCV2 specific nucleic acids with virus loads of $1.46 \times 10^{6}, 1.35 \times 10^{7}$, and $7.25 \times 10^{6} \mathrm{GE} / \mathrm{mL}$ sample. These three individuals were in good body condition, and both age groups and sexes were represented. PCV3 could not be detected in any wild ruminant.

Porcine lymphotropic herpesviruses (PLHV) were frequently detected in the wild boar samples (74\% individuals tested positive in 2019 and 91.1\% in 2020) (Figure 2), as single, double, or triple infections.
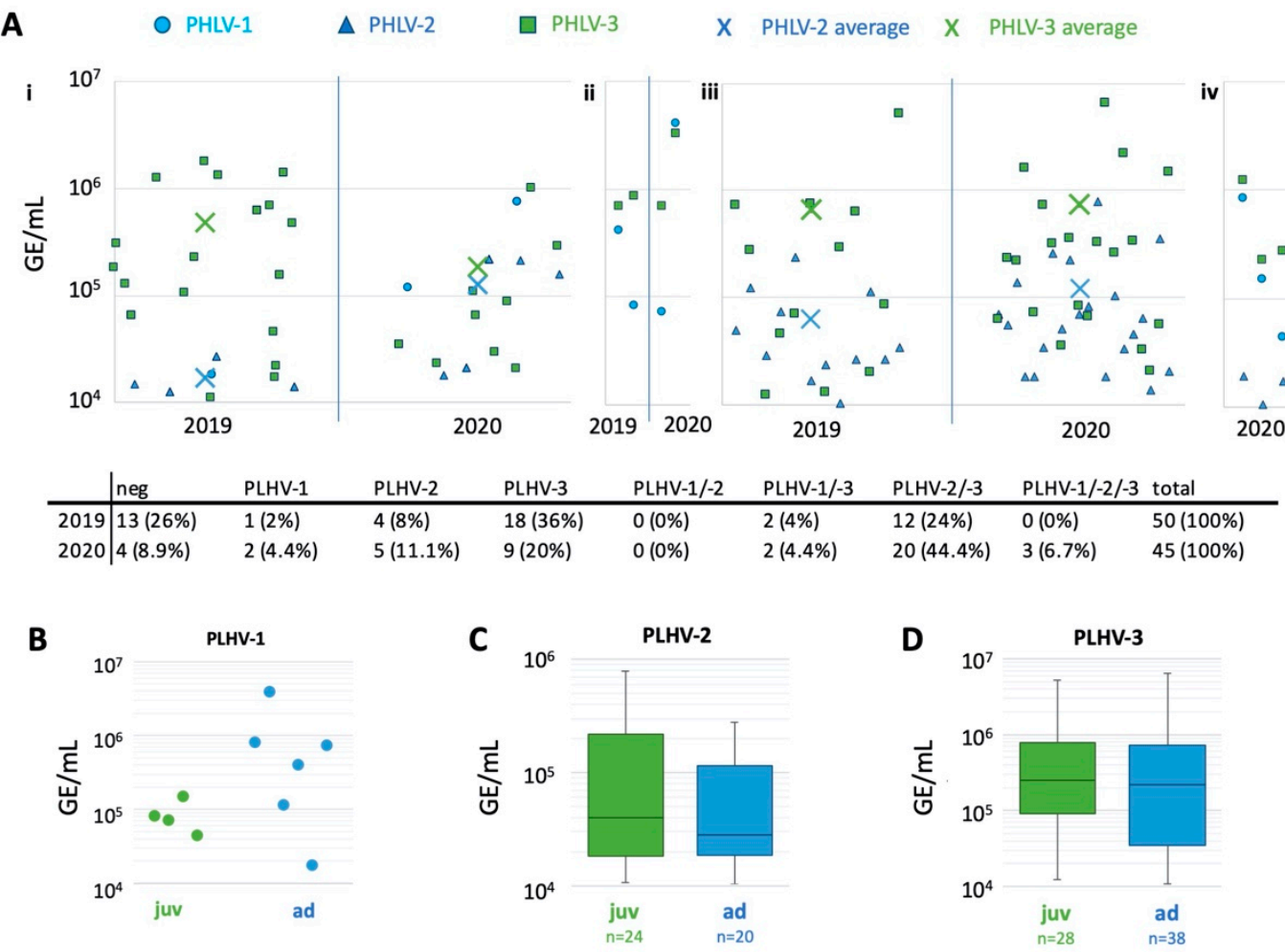

Figure 2. Virus loads of PLHVs in wild boar samples in 2019 and 2020. (A) PLHV-1 is indicated by cyan dots, PLHV-2 by blue triangles, PLHV-3 by green squares, and the averages by crosses. If several viruses were detected in the same sample, the values for the different PLHV species are given on the same location of the X-axis. (i) Viral loads in wild boar infected with one PLHV. (ii) Viral loads in wild boar infected with PLHV-1 and -3. (iii) Viral loads in wild boar infected with PLHV-2 and -3. (iv) Viral loads in wild boar infected with all three PLHVs. The number of animals belonging to each category is given in the table below the graphs. (B-D) Virus loads of PLHVs depending on the age of the sampled wild boar.

The dominant species was PLHV-3. It was present in 32 samples in $2019(64 \%)$ and 34 (samples) in 2020 (76\%). PLHV-2 was detected in 16 samples in 2019 (32\%) and 28 samples in 2020 (62.2\%). PLHV-1 was least represented in the population, with three positive wild boars in $2019(6 \%)$ and seven positive wild boars in 2020 (16\%). The predominant PLHV infection was co-infection of PLHV-2 and -3, which was detected in 32 wild boars during the study period (34\%). Interestingly, no co-infection of PLHV-1 and -2 was observed, while three triple infections with PLHV-1, -2, and -3 were detected in 2020 (6.7\%). 
Viral loads in GE/mL sample ranged from $1.8 \times 10^{4}$ to $4.0 \times 10^{6}$ for PLHV- 1 (average $6.4 \times 10^{5}$ ), from $1.0 \times 10^{4}$ to $7.8 \times 10^{5}$ for PLHV-2 (average $9.0 \times 10^{4}$ ), and from $1.1 \times 10^{4}$ to $5.1 \times 10^{6}$ for PLHV-3 (average $6.1 \times 10^{5}$ ). No statistically significant association of GE levels and co-infection was observed. PLHV viral loads did not significantly differ between juvenile and adult animals (Figure 2B-D), but PLHV-1 loads were generally lower in juvenile animals.

It is still unclear whether PLHV infections are associated with additional comorbidities. To gather further evidence, we analyzed the virus loads of PCV2, PCV3, and PLHV-1 to -3 , taking signs of parasite burden-defined as the presence of intestinal parasites, milk spots, and lung worms-as observed during necropsy into account. A significant association between viral loads and lesions found at necropsy was observed in two cases (Supplementary Figure S1). Lower viral loads of PCV2 and PLHV-3 were observed when intestinal parasites were absent.

Herpesviruses were detected in 12 out of 75 ruminant samples (16\%; four animals in 2019 and eight animals in 2020) by PCR (Table 1). Sequence analysis of the PCR products revealed the closest similarity to fallow deer herpesvirus in ten cases (two samples derived from fallow deer and eight derived from red deer), and two sequences (162 bp) derived from red deer were closest related (99.4\%) to elk gammaherpesvirus (GenBank: KY612411.1.)

Table 1. Detection of herpesviruses in deer. The herpesvirus species was determined by sequence analysis of the final PCR product.

\begin{tabular}{ccc}
\hline & $\mathbf{2 0 1 9}$ & $\mathbf{2 0 2 0}$ \\
\hline fallow deer herpesvirus & $3(7.7 \%)$ & $7(19.4 \%)$ \\
elk gamma herpesvirus & $1(2.6 \%)$ & $1(2.8 \%)$ \\
no herpesvirus & $35(89.7 \%)$ & $28(77.8 \%)$ \\
sum & 39 & 36
\end{tabular}

$\overline{\operatorname{PrV}(\text { SuHV-1) infections in wild boar and pestivirus infections in wild ruminants were not detected by (RT-)PCR. }}$

\section{Discussion}

In the present study, 170 game animals living in a $12 \mathrm{~km}^{2}$ game reserve shot during canned hunts in 2019 and 2020 were sampled and screened for different viruses. Highquality sampling of such large numbers of animals in a time- and cost-efficient manner remains challenging. To accelerate this process and avoid cross-contamination and the need for large numbers of sterile and DNA-free knives, scissors, and tweezers, tissue samples were aspirated using sterile syringes and large-bore needles. Subsequently, the tissue material could be processed under sterile laboratory conditions. We consider this way of sampling tissue of shot animals very practical and time effective, while the risk of cross-contamination is minimized.

Monitoring animal populations for known and novel pathogens is a key aspect to assess the risk -in the case of known animal pathogens-of transmission to domestic animals and spill-over events. Additionally, it is central to monitor the health status of a population and provides novel insights into disease dynamics. In this study, the presence of several pathogens was for the first time analyzed in a quantitative manner in an Austrian game population.

According to known literature, PCV2 prevalence in wild boar populations shows high variations in different regions. Hammer et al. (2012) found feral pig populations of three woodland areas in Baden-Wurtemburg (Germany) to be $17 \%, 37 \%$, and $98 \%$ positive for PCV2 specific nucleic acids. In a study by Reiner et al. (2010) [11], 522 wild boar samples from 14 German districts showed a mean qPCR positivity of $45 \%$. In the population studied here, $74 \%$ of wild boar samples tested positive for PCV2, placing our population towards the upper end of the reported prevalence in central Europe. We determined mean viral loads of $1.15 \times 10^{10} \mathrm{GE} / \mathrm{mL}$ tissue and swab lysate, which is high compared to Hammer et al. (2012) [13], who published mean viral loads of $\sim 2.51 \times 10^{8} \mathrm{GE} / \mathrm{mL}$ tissue lysate. Reiner et al. (2010) [11] reported $10^{2.8} \mathrm{GE} / \mu \mathrm{g}$ DNA on average. The significant 
difference in PCV2 viral loads in our study population between the two sampling events was likely caused by the high PCV2 viral loads in juvenile animals in 2020, and indicates an acute outbreak of PCV2, which would increase the likelihood of clinical disease [64]. However, no increase in overtly diseased animals was observed by the hunters surveilling the resort (personal communication), indicating that high viral loads are less likely to be associated with overt disease in wild boars than in domestic pigs. More data, including detailed patho-histological examination of organs and population details, are needed to test this hypothesis.

PCV3 was less prevalent in this wild boar population than PCV2. It was detectable by qPCR in $25 \%$ of wild boar samples, which compared well to findings from Italy [65], where $30 \%$ of wild boars tested positive. The reported prevalence of PCV3 in two feral pig populations around Berlin (Germany) was 23\% and 50\%, respectively [15]. In our study, double infections of PCV2 and -3 occurred at a rate of $23 \%$. This was considerably higher than the $12.5 \%$ and $7.5 \%$, respectively, reported by Prinz et al. (2019) [15] for Germany. Interestingly, PCV3 was significantly more prevalent in adult animals, while viral loads between juvenile and adult animals were comparable, suggesting a higher susceptibility/likelihood of exposure of adult animals. Our findings support the theory that PCV3 is endemic globally [66]. However, whether PCV3 infection has a detrimental impact for wild animal health is still a matter of debate.

Despite their name, PCVs can also be found in other species than swine, such as ruminants, which Wang et al. (2018) [39] and Zhai et al. (2019) [41] showed for PCV2, and Franzo et al. (2019) [37] showed for PCV3. In our study, three red deer samples (4.7\% of red deer) tested positive for PCV2 with relatively low viral loads of $1.46 \times 10^{6}, 1.35 \times 10^{7}$, and $7.25 \times 10^{6} \mathrm{GE} / \mathrm{mL}$ tissue and swab lysate. In contrast, PCV3 qPCRs of all ruminant samples produced negative results. The recently discovered PCV4 $[67,68]$ was not included in this study, but should be considered in future epidemiological investigations.

PrV-specific nucleic acids could not be amplified from any porcine sample, implying a low virus prevalence and hence a low risk for transmission to the domestic pig population or dead-end hosts such as hunting dogs.

In both ruminant and wild boar samples, gammaherpesvirus infections seem to be common. PLHV specific nucleic acids were detected in 78 out of 95 (82\%) wild boar samples, with PLHV-3 being the most prevalent herpesvirus in this study (69\%), followed by PLHV2 (46\%) and PLHV-1 (11\%). This is in contrast to findings from domestic swine from Germany, Italy, and Ireland, where PLHV-1 was most prevalent with 54\% [49], 29\% [50], and 74\% [69], respectively. The prevalence of PLHV-2 ranged from 11-45\% and of PLHV3 from $4.5-48 \%[49,50,69]$. In these studies, a co-infection of PLHV-1 and -3 was most frequently observed, followed by co-infections with PLHV-1 and -2 [50,69], or with all three PLHVs [49]. In the population presented here, no co-infections of PLHV-1 and -2 were observed, but co-infection with PLHV-2 and -3 was most frequently observed. Therefore, it should be further elucidated whether the dynamics of PLHV infections differ between domestic pigs and wild boar, and whether the geographical area and the organ sampled affects prevalence. Interestingly, the viral loads reported by Franzo [50] in domestic pigs were the highest for PLHV-2, while the viral loads in the presented study were highest for PLHV-3. PLHV-3 is genetically more distinct from PLHV-1 and -2 , which were detected in feral pigs previously [48,49]. Franzo et al. (2021) [50], and McMahon et al. (2006) [69], did not observe any connections between gammaherpesvirus infections and disease in domestic pigs. From the data available in this study, there is no evidence that PLHVs are associated with either a lower body condition score or increased comorbidities at necropsy in the studied wild boar population, apart from a lower viral load of PLHV-3 when intestinal parasites were absent. A slight variation (not significant) was also observed for PHLV-1, with seemingly higher viral loads in adult animals. No statistically significant variation in PLHV virus loads was detectable between the samples in 2019 and 2020. This finding indicates a constant, low-level replication of PLHVs in this wild boar population. 
Some gammaherpesviruses of small ruminants (OvHV-2, CpHV-2, and AlHV-1) are known to cause malignant catarrhal fever in other species $[53,54,70,71]$, but none of these MCF associated viruses were detectable by pan-herpesvirus PCR in the wild ruminant samples.

However, in two red deer samples, sequences closest related to elk gammaherpesvirus were identified, which supports findings from China [57], postulating that this virus is adapted to other deer species besides elk. Sequences similar to fallow deer herpesvirus, which belong to the genus Rhadinovirus, were present in eight red deer and two fallow deer samples. Again, the clinical relevance of these viruses is unclear, but should not be neglected.

As a part of a monitoring program from 2007 to 2009, the Institute for Veterinary Investigations of the AGES (Austrian Agency for Health and Food Safety) tested 700 red deer samples as negative for the presence of BVDV via AG-ELISA and RT-qPCR [72]. One BVDV-1 antibody positive, 9-year-old male red deer was identified in a study published 2004 [60], in which 133 wild ruminants were tested. These surveillance data indicate that the prevalence of BVDV circulation in wildlife in Austria is low. In our study, no pestivirusspecific nucleic acids were detectable in any of the samples. Therefore, a low to absent circulation of pestiviruses in the sampled population can be assumed.

\section{Materials and Methods}

\subsection{Animals and Samples}

Samples were derived from animals shot during the annual driven hunts in autumn 2019 and 2020 in a private game enclosure in eastern Austria. The enclosure was approximately $12 \mathrm{~km}^{2}$ in size and fenced off by high stone walls, making it highly unlikely that the animals had direct contact with free-ranging animals from outside. It is estimated-based on the results of the yearly hunt and observations of the local hunters-that the population consisted of approximately 300 red deer and 450 wild boars. The population could be considered a closed game population as no animals had been restocked for ten years. Supplementary food was provided to the animals.

The samples consisted of organs from 64 red deer (Cervus elaphus), 5 fallow deer (Dama dama), 6 mouflon (Ovis gmelini musimon), and 95 wild boars (Sus scrofa). Estimated age, nutrition status, and species are shown in Supplementary Table S2. All animals were shot by hunters. Sampling and necropsy were performed on-site 1-3 h after death.

After the body cavities were opened, tissue samples were gained by aspiration of the lung and spleen tissue through a large-bore needle $(14 \mathrm{G})$ into a sterile $10 \mathrm{~mL}$ disposable syringe. Additionally, tonsillar swabs were taken; samples were frozen at $-80{ }^{\circ} \mathrm{C}$ until further processing.

\subsection{Nucleic Acid Extraction and PCRs}

Approximately $100 \mathrm{mg}$ of spleen and lung samples were tissue lysed (Tissue lyser II, Qiagen, Germany) in $1 \mathrm{~mL}$ PBS and centrifuged at $16.000 \times g$ for $3 \mathrm{~min}$. Tonsillar swabs were vortexed for $10 \mathrm{~s}$ in $1 \mathrm{~mL}$ sterile PBS. Equal parts of swab lysate and supernatant of the tissue lysate were pooled, and $200 \mu \mathrm{L}$ were extracted employing the QIAamp 96 Virus QIAcube HT Kit using QIAcube HT (Qiagen, Hilden, Germany) according to the manufacturer's instructions.

A PCV2 and PCV3 assay analyzing all 170 samples was carried out as a duplex qPCR. Only wild boar extracts were screened for PLHV-1, -2 , and -3 by three individual qPCRs. A 10-fold dilution series of defined DNA plasmid standards were tested side by side with the samples for absolute quantification. The samples were considered positive if the qPCR demonstrated more than $10^{5}$ copies/mL (PCV2/PCV3) and $10^{4}$ copies $/ \mathrm{mL}$ tissue and swab lysate (PLHV-1/PLHV-2/PLHV-3), respectively. All qPCRs were carried out in a Rotor-Gene Q 5-plex machine (Qiagen, Hilden, Germany).

For detection of herpesvirus-specific DNA and RNA of classical pestiviruses (BVDV and BDV) in ruminants and PrV specific DNA of wild boar samples, extracts were analyzed 
in pools of five. RT-PCR products were visualized using the capillary electrophoresis device QIAxcel Advanced System (Qiagen, Hilden, Germany). In the case of positive results, the respective pool was opened, and samples were analyzed individually.

Specific PCR products generated in the pan-PCRs were sanger sequenced (Eurofins Genomics, Ebersberg, Germany) and compared to published sequences with BLAST (NCBI, Bethesda, MD, USA).

Primer and probe sequences, as well as used PCR kits, are shown in Supplementary Table S3 [27,49,73-76].

\subsection{Statistical Analysis}

Statistical analysis was performed to assess the significance of results employing the Student's $t$-test or-in the case of qualitative data-the Fisher's exact test.

\section{Conclusions}

The presented data demonstrate a high prevalence of PLHVs and PCV2 in a closed wild boar population in Austria, and are the first quantitative data on PLHV-1 to -3 loads in wild boar. The studied population was free from important, notifiable pathogens such as PrV and BVDV, suggesting a low risk of spill-over into the domestic animal population.

Supplementary Materials: The following supporting information can be downloaded at https: //www.mdpi.com/article/10.3390/pathogens11030305/s1. Table S1: All data used in this study. Table S2: Number of animals in the study, depending on sex and age, weight, and body score. Table S3: Primer, probes and kits employed in this study. Figure S1: Association of parasite burden/parasitic lesions with viral loads.

Author Contributions: Conceptualization: A.A., C.R., A.K.-H. and A.P.; methodology: A.A., C.R., A.K.-H. and A.P.; investigation: K.D., L.S. and C.B.; data curation: C.R. and A.A.; writing-original draft preparation: A.A.; writing—review and editing: C.R., T.R. and K.S.; visualization: C.R.; supervision: C.R. and T.R.; project administration: A.A. All authors have read and agreed to the published version of the manuscript.

Funding: The investigations were partly funded by the owner of the game reserve (who wants to stay anonymous); parts of the virological investigations were self-funded by the Institute of Virology (Vetmeduni Vienna).

Institutional Review Board Statement: Not applicable.

Informed Consent Statement: Not applicable.

Data Availability Statement: Not applicable.

Acknowledgments: The authors thank K. Walk, K. Szakmary-Brändle, and H. Dier for their excellent technical support. Open Access Funding by the University of Veterinary Medicine Vienna.

Conflicts of Interest: The authors declare no conflict of interest. The funders had no role in the design of the study; in the collection, analyses, or interpretation of data; in the writing of the manuscript; or in the decision to publish the results.

\section{References}

1. Segalés, J.; Piella, J.; Marco, E.; Mateu-de-Antonio, E.M.; Espuña, E.; Domingo, M. Porcine dermatitis and nephropathy syndrome in Spain. Vet. Rec. 1998, 142, 483-486. [CrossRef] [PubMed]

2. Segalés, J.; Rosell, C.; Domingo, M. Pathological findings associated with naturally acquired porcine circovirus type 2 associated disease. Vet. Microbiol. 2004, 98, 137-149. [CrossRef] [PubMed]

3. Ellis, J.; Krakowka, S.; Lairmore, M.; Haines, D.; Bratanich, A.; Clark, E.; Allan, G.; Konoby, C.; Hassard, L.; Meehan, B.; et al. Reproduction of lesions of postweaning multisystemic wasting syndrome in gnotobiotic piglets. J. Vet. Diagn. Investig. 1999, 11, 3-14. [CrossRef] [PubMed]

4. Harding, J.C.S. The clinical expression and emergence of porcine circovirus 2. Vet. Microbiol. 2004, 98, 131-135. [CrossRef] [PubMed]

5. Chae, C. A review of porcine circovirus 2-associated syndromes and diseases. Vet. J. 2005, 169, 326-336. [CrossRef] 
6. Ellis, J.; Spinato, M.; Yong, C.; West, K.; McNeilly, F.; Meehan, B.; Kennedy, S.; Clark, E.; Krakowka, S.; Allan, G. Porcine circovirus 2-associated disease in Eurasian wild boar. J. Vet. Diagn. Investig. 2003, 15, 364-368. [CrossRef]

7. Toplak, I.; Grom, J.; Hostnik, P.; Barlič-Maganja, D. Phylogenetic analysis of type 2 porcine circoviruses indentified in wild boar in Slovenia. Vet. Rec. 2004, 155, 178-180. [CrossRef]

8. Vicente, J.; Segalés, J.; Höfle, U.; Balasch, M.; Plana-Durán, J.; Domingo, M.; Gortázar, C. Epidemiological study on porcine circovirus type 2 (PCV 2) infection in the European wild boar (Sus scrofa). Vet. Res. 2004, 35, 243-253. [CrossRef]

9. Cságola, A.; Kecskeméti, S.; Kardos, G.; Kiss, I.; Tuboly, T. Genetic characterization of type 2 porcine circoviruses detected in Hungarian wild boars. Arch. Virol. 2006, 151, 495-507. [CrossRef]

10. Cadar, D.; Cságola, A.; Spinu, M.; Dán, D.; Ursu, K.; Lorincz, M.; Tuboly, T. Prevalence of porcine circoviruses in Transylvanian wild boars, detected by real-time PCR-Short communication. Acta Vet. Hung. 2010, 58, 475-481. [CrossRef]

11. Reiner, G.; Bronnert, B.; Hohloch, C.; Fresen, C.; Haack, I.; Willems, H.; Reinacher, M. Qualitative and quantitative distribution of PCV2 in wild boars and domestic pigs in Germany. Vet. Microbiol. 2010, 145, 1-8. [CrossRef] [PubMed]

12. Boadella, M.; Ruiz-Fons, J.F.; Vicente, J.; Martín, M.; Segalés, J.; Gortazar, C. Seroprevalence evolution of selected pathogens in iberian wild boar. Transbound. Emerg. Dis. 2012, 59, 395-404. [CrossRef] [PubMed]

13. Hammer, R.; Ritzmann, M.; Palzer, A.; Lang, C.; Hammer, B.; Pesch, S.; Ladinig, A. Porcine Reproductive and Respiratory Syndrome Virus and Porcine Circovirus Type 2 Infections in Wild Boar (Sus Scrofa) in Southwestern Germany. J. Wildl. Dis. 2012, 48, 87-94. [CrossRef] [PubMed]

14. Fabisiak, M.; Podgórska, K.; Skrzypiec, E.; Szczotka, A.; Stadejek, T. Detection of porcine circovirus type 2 (PCV2) and porcine reproductive and respiratory syndrome virus (PRRSV) antibodies in meat juice samples from Polish wild boar (Sus scrofa L.). Acta Vet. Hung. 2013, 61, 529-536. [CrossRef]

15. Prinz, C.; Stillfried, M.; Neubert, L.K.; Denner, J. Detection of PCV3 in German wild boars. Virol. J. 2019, 16, 25. [CrossRef]

16. Ouyang, T.; Niu, G.; Liu, X.; Zhang, X.; Zhang, Y.; Ren, L. Recent progress on porcine circovirus type 3. Infect. Genet. Evol. 2019, 73, 227-233. [CrossRef]

17. Phan, T.G.; Giannitti, F.; Rossow, S.; Marthaler, D.; Knutson, T.; Li, L.; Deng, X.; Resende, T.; Vannucci, F.; Delwart, E. Detection of a novel circovirus PCV3 in pigs with cardiac and multi-systemic inflammation. Virol. J. 2016, 13, 184. [CrossRef]

18. Faccini, S.; Barbieri, I.; Gilioli, A.; Sala, G.; Gibelli, L.R.; Moreno, A.; Sacchi, C.; Rosignoli, C.; Franzini, G.; Nigrelli, A. Detection and genetic characterization of Porcine circovirus type 3 in Italy. Transbound. Emerg. Dis. 2017, 64, 1661-1664. [CrossRef]

19. Wen, S.; Sun, W.; Li, Z.; Zhuang, X.; Zhao, G.; Xie, C.; Zheng, M.; Jing, J.; Xiao, P.; Wang, M.; et al. The detection of porcine circovirus 3 in Guangxi, China. Transbound. Emerg. Dis. 2018, 65, 27-31. [CrossRef]

20. Yuzhakov, A.G.; Raev, S.A.; Alekseev, K.P.; Grebennikova, T.V.; Verkhovsky, O.A.; Zaberezhny, A.D.; Aliper, T.I. First detection and full genome sequence of porcine circovirus type 3 in Russia. Virus Genes 2018, 54, 608-611. [CrossRef]

21. Ye, X.; Berg, M.; Fossum, C.; Wallgren, P.; Blomström, A.L. Detection and genetic characterisation of porcine circovirus 3 from pigs in Sweden. Virus Genes 2018, 54, 466-469. [CrossRef] [PubMed]

22. Arruda, B.; Piñeyro, P.; Derscheid, R.; Hause, B.; Byers, E.; Dion, K.; Long, D.; Sievers, C.; Tangen, J.; Williams, T.; et al. PCV3-associated disease in the United States swine herd. Emerg. Microbes Infect. 2019, 8, 684-698. [CrossRef]

23. Deim, Z.; Dencso, L.; Erdélyi, I.; Valappil, S.K.; Varga, C.; Pósa, A.; Makrai, L.; Rákhely, G. Porcine circovirus type 3 detection in a Hungarian pig farm experiencing reproductive failures. Vet. Rec. 2019, 185, 84. [CrossRef] [PubMed]

24. Geng, S.; Luo, H.; Liu, Y.; Chen, C.; Xu, W.; Chen, Y.; Li, X.; Fang, W. Prevalence of porcine circovirus type 3 in pigs in the southeastern Chinese province of Zhejiang. BMC Vet. Res. 2019, 15, 244. [CrossRef] [PubMed]

25. Jiang, H.; Wang, D.; Wang, J.; Zhu, S.; She, R.; Ren, X.; Tian, J.; Quan, R.; Hou, L.; Li, Z.; et al. Induction of Porcine Dermatitis and Nephropathy Syndrome in Piglets by Infection with Porcine Circovirus Type 3. J. Virol. 2019, 93, e02045-18. [CrossRef] [PubMed]

26. Sukmak, M.; Thanantong, N.; Poolperm, P.; Boonsoongnern, A.; Ratanavanichrojn, N.; Jirawattanapong, P.; Woonwong, Y.; Soda, N.; Kaminsonsakul, T.; Phuttapatimok, S.; et al. The retrospective identification and molecular epidemiology of porcine circovirus type 3 (PCV3) in swine in Thailand from 2006 to 2017. Transbound. Emerg. Dis. 2019, 66, 611-616. [CrossRef] [PubMed]

27. Palinski, R.; Piñeyro, P.; Shang, P.; Yuan, F.; Guo, R.; Fang, Y.; Byers, E.; Hause, B.M. A Novel Porcine Circovirus Distantly Related to Known Circoviruses Is Associated with Porcine Dermatitis and Nephropathy Syndrome and Reproductive Failure. J. Virol. 2017, 91, e01879-16. [CrossRef]

28. Kwon, T.; Yoo, S.J.; Park, C.K.; Lyoo, Y.S. Prevalence of novel porcine circovirus 3 in Korean pig populations. Vet. Microbiol. 2017, 207, 178-180. [CrossRef]

29. Stadejek, T.; Woźniak, A.; Miłek, D.; Biernacka, K. First detection of porcine circovirus type 3 on commercial pig farms in Poland. Transbound. Emerg. Dis. 2017, 64, 1350-1353. [CrossRef]

30. Zhai, S.L.; Zhou, X.; Zhang, H.; Hause, B.M.; Lin, T.; Liu, R.; Chen, Q.L.; Wei, W.K.; Lv, D.H.; Wen, X.H.; et al. Comparative epidemiology of porcine circovirus type 3 in pigs with different clinical presentations. Virol. J. 2017, 14, 4-9. [CrossRef]

31. Franzo, G.; Legnardi, M.; Hjulsager, C.K.; Klaumann, F.; Larsen, L.E.; Segales, J.; Drigo, M. Full-genome sequencing of porcine circovirus 3 field strains from Denmark, Italy and Spain demonstrates a high within-Europe genetic heterogeneity. Transbound. Emerg. Dis. 2018, 65, 602-606. [CrossRef] [PubMed]

32. Hayashi, S.; Ohshima, Y.; Furuya, Y.; Nagao, A.; Oroku, K.; Tsutsumi, N.; Sasakawa, C.; Sato, T. First detection of porcine circovirus type 3 in Japan. J. Vet. Med. Sci. 2018, 80, 1468-1472. [CrossRef] [PubMed] 
33. Kedkovid, R.; Woonwong, Y.; Arunorat, J.; Sirisereewan, C.; Sangpratum, N.; Lumyai, M.; Kesdangsakonwut, S.; Teankum, K.; Jittimanee, S.; Thanawongnuwech, R. Porcine circovirus type 3 (PCV3) infection in grower pigs from a Thai farm suffering from porcine respiratory disease complex (PRDC). Vet. Microbiol. 2018, 215, 71-76. [CrossRef] [PubMed]

34. Tochetto, C.; Lima, D.A.; Varela, A.P.M.; Loiko, M.R.; Paim, W.P.; Scheffer, C.M.; Herpich, J.I.; Cerva, C.; Schmitd, C.; Cibulski, S.P.; et al. Full-Genome Sequence of Porcine Circovirus type 3 recovered from serum of sows with stillbirths in Brazil. Transbound. Emerg. Dis. 2018, 65, 5-9. [CrossRef]

35. Klaumann, F.; Dias-Alves, A.; Cabezón, O.; Mentaberre, G.; Castillo-Contreras, R.; López-Béjar, M.; Casas-Díaz, E.; Sibila, M.; Correa-Fiz, F.; Segalés, J. Porcine circovirus 3 is highly prevalent in serum and tissues and may persistently infect wild boar (Sus scrofa scrofa). Transbound. Emerg. Dis. 2019, 66, 91-101. [CrossRef]

36. Zhang, J.; Liu, Z.; Zou, Y.; Zhang, N.; Wang, D.; Tu, D.; Yang, L.; Deng, Z.; Yang, Y.; Jiang, P.; et al. First molecular detection of porcine circovirus type 3 in dogs in China. Virus Genes 2018, 54, 140-144. [CrossRef]

37. Franzo, G.; Grassi, L.; Tucciarone, C.M.; Drigo, M.; Martini, M.; Pasotto, D.; Mondin, A.; Menandro, M.L. A wild circulation: High presence of Porcine circovirus 3 in different mammalian wild hosts and ticks. Transbound. Emerg. Dis. 2019, 66, 1548-1557. [CrossRef]

38. Jiang, S.; Zhou, N.; Li, Y.; An, J.; Chang, T. Detection and sequencing of porcine circovirus 3 in commercially sourced laboratory mice. Vet. Med. Sci. 2019, 5, 176-181. [CrossRef]

39. Wang, X.; Li, W.; Xu, X.; Wang, W.; He, K.; Fan, H. Phylogenetic analysis of two goat-origin PCV2 isolates in China. Gene 2018, 651,57-61. [CrossRef]

40. Wang, W.; Sun, W.; Cao, L.; Zheng, M.; Zhu, Y.; Li, W.; Liu, C.; Zhuang, X.; Xing, J.; Lu, H.; et al. An epidemiological investigation of porcine circovirus 3 infection in cattle in Shandong province, China. BMC Vet. Res. 2019, 15, 60. [CrossRef]

41. Zhai, S.L.; Lu, S.S.; Wei, W.K.; Lv, D.H.; Wen, X.H.; Zhai, Q.; Chen, Q.L.; Sun, Y.W.; Xi, Y. Reservoirs of Porcine Circoviruses: A Mini Review. Front. Vet. Sci. 2019, 6, 319. [CrossRef] [PubMed]

42. Steinrigl, A.; Revilla-Fernández, S.; Kolodziejek, J.; Wodak, E.; Bagó, Z.; Nowotny, N.; Schmoll, F.; Köfer, J. Detection and molecular characterization of Suid herpesvirus type 1 in Austrian wild boar and hunting dogs. Vet. Microbiol. 2012, 157, 276-284. [CrossRef] [PubMed]

43. Meier, R.K.; Ruiz-Fons, F.; Ryser-Degiorgis, M.P. A picture of trends in Aujeszky's disease virus exposure in wild boar in the Swiss and European contexts. BMC Vet. Res. 2015, 11, 277. [CrossRef] [PubMed]

44. Caruso, C.; Vitale, N.; Prato, R.; Radaelli, M.C.; Zoppi, S.; Possidente, R.; Dondo, A.; Chiavacci, L.; Moreno Martin, A.M.; Masoero, L. Pseudorabies virus in North-West Italian wild boar (Sus scrofa) populations: Prevalence and risk factors to support a territorial risk-based surveillance. Vet. Ital. 2018, 54, 337-341. [CrossRef] [PubMed]

45. Denzin, N.; Conraths, F.J.; Mettenleiter, T.C.; Freuling, C.M.; Müller, T. Monitoring of pseudorabies in wild boar of Germany-A spatiotemporal analysis. Pathogens 2020, 9, 276. [CrossRef] [PubMed]

46. Müller, T.; Hahn, E.C.; Tottewitz, F.; Kramer, M.; Klupp, B.G.; Mettenleiter, T.C.; Freuling, C. Pseudorabies virus in wild swine: A global perspective. Arch. Virol. 2011, 156, 1691-1705. [CrossRef]

47. Laval, K.; Enquist, L.W. The neuropathic itch caused by pseudorabies virus. Pathogens 2020, 9, 254. [CrossRef]

48. Ulrich, S.; Goltz, M.; Ehlers, B. Characterization of the DNA polymerase loci of the novel porcine lymphotropic herpesviruses 1 and 2 in domestic and feral pigs. J. Gen. Virol. 1999, 80, 3199-3205. [CrossRef]

49. Chmielewicz, B.; Goltz, M.; Franz, T.; Bauer, C.; Brema, S.; Ellerbrok, H.; Beckmann, S.; Rziha, H.J.; Lahrmann, K.H.; Romero, C.; et al. A novel porcine gammaherpesvirus. Virology 2003, 308, 317-329. [CrossRef]

50. Franzo, G.; Drigo, M.; Legnardi, M.; Grassi, L.; Menandro, M.L.; Pasotto, D.; Cecchinato, M.; Tucciarone, C.M. Porcine gammaherpesviruses in italian commercial swine population: Frequent but harmless. Pathogens 2021, 10, 47. [CrossRef]

51. Ehlers, B.; Dural, G.; Yasmum, N.; Lembo, T.; de Thoisy, B.; Ryser-Degiorgis, M.-P.; Ulrich, R.G.; McGeoch, D.J. Novel Mammalian Herpesviruses and Lineages within the Gammaherpesvirinae: Cospeciation and Interspecies Transfer. J. Virol. 2008, 82, 3509-3516. [CrossRef] [PubMed]

52. Plowright, W.; Ferris, R.D.; Scott, G.R. Blue wildebeest and the Ætiological agent of bovine malignant catarrhal fever. Nature 1960 188, 1167-1169. [CrossRef] [PubMed]

53. Plowright, W. Malignant Catarrhal Fever Virus. In Virus Infections of Ruminants; Elsevier: Amsterdam, The Netherlands, 1990.

54. Løken, T.; Aleksandersen, M.; Reid, H.W.; Pow, I. Malignant catarrhal fever caused by ovine herpesvirus-2 in pigs in Norway. Vet. Rec. 1998, 143, 464-467. [CrossRef] [PubMed]

55. Crawford, T.B.; Li, H.; Rosenburg, S.R.; Norhausen, R.W.; Garner, M.M. Mural folliculitis and alopecia caused by infection with goat-associated malignant catarrhal fever virus in two sika deer. J. Am. Vet. Med. Assoc. 2002, 221, 843-847. [CrossRef]

56. O'Toole, D.; Li, H. The Pathology of Malignant Catarrhal Fever, with an Emphasis on Ovine Herpesvirus 2. Vet. Pathol. 2014, 51, 437-452. [CrossRef]

57. Zhu, H.; Huang, Q.; Hu, X.; Chu, W.; Zhang, J.; Jiang, L.; Yu, X.; Zhang, X.; Cheng, S. Caprine herpesvirus 2-associated malignant catarrhal fever of captive sika deer (Cervus nippon) in an intensive management system. BMC Vet. Res. 2018, 14, 38. [CrossRef]

58. Li, H.; Gailbreath, K.; Flach, E.J.; Taus, N.S.; Cooley, J.; Keller, J.; Russell, G.C.; Knowles, D.P.; Haig, D.M.; Oaks, J.L.; et al. A novel subgroup of rhadinoviruses in ruminants. J. Gen. Virol. 2005, 86, 3021-3026. [CrossRef]

59. Zhu, H.; Liu, H.; Yu, X.; Zhang, J.; Jiang, L.; Chen, G.; Feng, Z.; Li, Y.; Feng, T.; Zhang, X. Evidence of two genetically different lymphotropic herpesviruses present among red deer, sambar, and milu herds in China. J. Vet. Sci. 2018, 19, 716-720. [CrossRef] 
60. Krametter, R.; Nielsen, S.S.; Loitsch, A.; Froetscher, W.; Benetka, V.; Moestl, K.; Baumgartner, W. Pestivirus exposure in free-living and captive deer in Austria. J. Wildl. Dis. 2004, 40, 791-795. [CrossRef]

61. Casaubon, J.; Vogt, H.R.; Stalder, H.; Hug, C.; Ryser-Degiorgis, M.P. Bovine viral diarrhea virus in free-ranging wild ruminants in Switzerland: Low prevalence of infection despite regular interactions with domestic livestock. BMC Vet. Res. 2012, 8, 204. [CrossRef]

62. Fernández-Aguilar, X.; López-Olvera, J.R.; Marco, I.; Rosell, R.; Colom-Cadena, A.; Soto-Heras, S.; Lavín, S.; Cabezón, O. Pestivirus in alpine wild ruminants and sympatric livestock from the Cantabrian Mountains, Spain. Vet. Rec. 2016, 178, 586. [CrossRef] [PubMed]

63. Rodríguez-Prieto, V.; Kukielka, D.; Rivera-Arroyo, B.; Martínez-López, B.; de las Heras, A.I.; Sánchez-Vizcaíno, J.M.; Vicente, J. Evidence of shared bovine viral diarrhea infections between red deer and extensively raised cattle in south-central Spain. BMC Vet. Res. 2016, 12, 11. [CrossRef]

64. Unterweger, C.; Brunthaler, R.; Auer, A.; Fux, R.; Weissenbacher-Lang, C.; Ladinig, A. Reconsideration of the diagnostic criteria required for PCV2 reproductive disease. Vet. J. 2021, 272, 105660. [CrossRef]

65. Franzo, G.; Tucciarone, C.M.; Drigo, M.; Cecchinato, M.; Martini, M.; Mondin, A.; Menandro, M.L. First report of wild boar susceptibility to Porcine circovirus type 3: High prevalence in the Colli Euganei Regional Park (Italy) in the absence of clinical signs. Transbound. Emerg. Dis. 2018, 65, 957-962. [CrossRef]

66. Tan, C.Y.; Lin, C.; Ooi, P.T. What do we know about porcine circovirus 3 (PCV3) diagnosis so far? A review. Transbound. Emerg. Dis. 2021, 68, 2915-2935. [CrossRef] [PubMed]

67. Zhang, H.H.; Hu, W.Q.; Li, J.Y.; Liu, T.N.; Zhou, J.Y.; Opriessnig, T.; Xiao, C.T. Novel circovirus species identified in farmed pigs designated as Porcine circovirus 4, Hunan province, China. Transbound. Emerg. Dis. 2020, 67, 1057-1061. [CrossRef] [PubMed]

68. Franzo, G.; Ruiz, A.; Grassi, L.; Sibila, M.; Drigo, M.; Segalés, J. Lack of porcine circovirus 4 genome detection in pig samples from Italy and Spain. Pathogens 2020, 9, 433. [CrossRef]

69. McMahon, K.J.; Minihan, D.; Campion, E.M.; Loughran, S.T.; Allan, G.; McNeilly, F.; Walls, D. Infection of pigs in Ireland with lymphotropic $\gamma$-herpesviruses and relationship to postweaning multisystemic wasting syndrome. Vet. Microbiol. 2006, 116, 60-68. [CrossRef]

70. Reid, H.W.; Buxton, D.; Corrigall, W.; Hunter, A.R.; McMartin, D.A.; Rushton, R. An outbreak of malignant catarrhal fever in red deer (Cervus elephus). Vet. Rec. 1979, 104, 120-123. [CrossRef]

71. Albini, S.; Zimmermann, W.; Neff, F.; Ehlers, B.; Häni, H.; Li, H.; Hüssy, D.; Casura, C.; Engels, M.; Ackermann, M. Porcines Bösartiges Katarrhalfieber: Diagnostische Befunde und erstmaliger Nachweis des Erregers bei erkrankten Schweinen in der Schweiz. Schweiz. Arch. Tierheilkd. 2003, 145, 61-68. [CrossRef]

72. Glawischnig, W.; Schoepf, K.; Matt, M. Monitoring for bovine viral diarrhea virus in austrian red deer (Cervus elaphus elaphus) by using ear-notch samples. J. Wildl. Dis. 2010, 46, 1269-1273. [CrossRef] [PubMed]

73. Vandevanter, D.R.; Warrener, P.; Bennett, L.; Schultz, E.R.; Coulter, S.; Garber, R.L.; Rose, T.M. Detection and analysis of diverse herpesviral species by consensus primer PCR. J. Clin. Microbiol. 1996, 34, 1666-1671. [CrossRef] [PubMed]

74. Mengeling, W.L.; Lager, K.M.; Volz, D.M.; Brockmeier, S.L. Effect of various vaccination procedures on shedding, latency, and reactivation of attenuated and virulent pseudorabies virus in swine. Am. J. Vet. Res. 1992, 53, 2164-2173. [PubMed]

75. Kadir, Y.; Christine, F.; Barbara, B.W.; Zeki, Y.; Feray, A.; Aykut, O.; Ibrahim, B.; Sibilina Cedillo, R.; Heinz-Jürgen, T.; Matthias, K. Genetic heterogeneity of bovine viral diarrhoea virus (BVDV) isolates from Turkey: Identification of a new subgroup in BVDV-1. Vet. Microbiol. 2008, 130, 258-267. [CrossRef] [PubMed]

76. Hoffmann, B. AVID-Methode_VIR02-pCV-2-qPCR-FLI. Available online: http://avid.dvg.net/fileadmin/Bilder/PDF_AVID_ Alt/website/Methoden_ab_2016/AVID-Methode_VIR02_porcines_Circovirus_2_final.pdf (accessed on 9 December 2021). 